\title{
СРАВНИТЕЛЬНЫЕ КОНСТРУКЦИИ С ЛИЧНЫМ ИМЕНЕМ И ОТТОПОНИМИЧЕСКИМ ПРИЛАГАТЕЛЬНЫМ В КОСТРОМСКИХ ГОВОРАХ ${ }^{1}$
}

\section{Юлия Александровна Кривощапова}

к. филол. н., доцент кафедры филологии Специализированного учебно-научного центра Уральский федеральный университет им. первого Президента России Б. Н. Ельцина 620137, Россия, г. Екатеринбург, ул. Данилы Зверева, 30. insekt@yandex.ru

SPIN-код: 2680-6403

ORCID: https://orcid.org/0000-0003-3096-708X

ResearcherID: Q-3496-2018

\section{Любовь Александровна Феоктистова}

к. филол. н., доцент кафедры русского языка, общего языкознания и речевой коммуникации Уральский федеральный университет им. первого Президента России Б. Н. Ельцина 620000, Россия, г. Екатеринбург, просп. Ленина, 51. 1.a.feoktistova@urfu.ru

SPIN-код: 2851-9740

ORCID: https://orcid.org/0000-0001-6640-4815

ResearcherID: T-7885-2017

Статья поступила в редакичию 08.09.2018

Просьба ссылаться на эту статью в русскоязычных источниках следующим образом:

Кривощапова Ю. А., Феоктистова Л. А. Сравнительные конструкции с личным именем и оттопонимимческим прилагательным в костромских говорах // Вестник Пермского университета. Российская и зарубежная филология. 2018. Т. 10, вып. 4. С. 30-42. doi 10.17072/2037-6681-2018-4-30-42

Please cite this article in English as:

Krivoshchapova Ju. A., Feoktistova L. A. Sravnitel'nyie konstruktsii s lichnym imenem i ottoponimicheskim prilagatelnym v kostomskikh govorakh [Comparative Structures with a Personal Name and an Adjective Derived from a Toponym, in the Dialects of the Kostroma Region]. Vestnik Permskogo universiteta. Rossiyskaya $i$ zarubezhnaya filologiya [Perm University Herald. Russian and Foreign Philology], 2018, vol. 10, issue 4, pp. 30-42. doi 10.17072/2037-6681-2018-4-30-42 (In Russ.)

На материале костромских говоров рассматриваются сравнительные конструкции, содержащие личное имя и прилагательное, образованное от ойконима: как Дуня каси́мовская (< д. Касимово) 'о нелепо одетой женщине', как Федя па́рюгский (< д. Малый Парюг) 'о сумасшедшем человеке', и др. Данные устойчивые сочетания характеризуют человека, чье поведение не соответствует нормам деревенского (хотя и не только) социума (ср. как Саня пе́номская 'о женщине, живущей вдали от других людей'). Эти конструкции рассматриваются с точки зрения их структуры и семантики, а также функций и ономастического статуса их составляющих. Авторы отмечают, что сравнение не всегда выражено эксплицитно и может включать различные предикаты (Что нарядился, как Анисья климовская?!; Анисья климовская идёm). Личное имя чаще представлено гипокористикой, оттопонимическое прилагательное обычно занимает постпозицию. Особое внимание уделяется анализу семантического «поведения» личного имени и адъектонима. По наблюдениям авторов, личные имена в сочетании с оттопонимическим прилагательным в составе сравнительных оборотов обладают теми же смысловыми особенностями, что и апеллятивные производные от одиночных личных имен: доминанта негативного, диффузность значения и / или полисемия, экспрессивность. Утверждается, что такие антропонимы выполняют функцию номинации-характеристики и находятся на первой ступени се- 
мантической деривации и апеллятивизации. Вместе с тем адъектоним в рамках устойчивого сочетания практически не подвергается смысловым трансформациям. Его базовая функция географической привязки объекта остается неизменной, что до некоторой степени сдерживает апеллятивизацию антропонима, напоминая о том, что в основе номинации лежит сопоставление с реальным человеком.

Ключевые слова: апеллятивизация имени собственного; антропоним; личное имя; оттопонимическое прилагательное; адъектоним; сравнительный оборот; фразеологизм; семантическая деривация; костромские говоры.

В ходе полевых сборов на территории Костромской области участниками Топонимической экспедиции УрФУ неоднократно фиксировались сравнительные конструкции, которые включают личное имя жителя какой-либо деревни и - зачастую - прилагательное, образованное от названия этой деревни ${ }^{2}$. См., например, как Дуня каси́мовская 'о нелепо одетой женщине': «У нас тут ещё одна ходила, как блаженная. Дуня касимовская. Вся юбка в пуговицах. Разные все и везде поподшиты. Ну и когда одета так, не пойми чего, говорят: "Ну, чего ты как Дуня касимовская!”» (Вохом.) ${ }^{3}$. Эти устойчивые, воспроизводимые в речи разных носителей одного говора сочетания представляют собой весьма любопытную разновидность прецедентной номинации. Само ее существование, надо полагать, обусловлено некоторыми особенностями коммуникации деревенского микросоциума.

Односельчане, будучи знакомыми с жителями окрестных деревень, для их идентификации в речи добавляют к личному имени оттопонимическое прилагательное. Сами же носители этих «прозвищ» нередко служат наглядным примером, «эталоном» того, что не соответствует принятой норме и осуждается социумом (какие-либо антропометрические характеристики, личностные качества, поведение). Е. Л. Березович считает, что таким образом деревенские жители удовлетворяют свою потребность в отпрецедентной номинации: имена исторических деятелей, литературных героев и т. п., нередко служащие этой цели, менее известны им и актуальны для них, соответственно, и макротопонимы, в отличие от местных названий, используются реже (см.: [Березович 2012: 42]).

В статье Е. Л. Березович устойчивые выражения с личным именем и адъектонимом рассматриваются по данным различных диалектных словарей в рамках модели «обозначение человека (в том числе апеллятив) + оттопонимическое прилагательное» в ономасиолого-мотивационном и семантическом планах (см.: [там же: 2552]). Цель предпринятого нами исследования описать структуру и семантику подобных отыменных номинаций, выявить их специфику. Отдельный вопрос - возможная лингвогеографическая информативность рассматриваемых языковых единиц, однако за недостатком материала по другим территориям в данной публикации он не рассматривается. Основным источником материала стала электронная база ТЭ УрФУ, содержащая полевые записи лексики и фразеологии костромских говоров (ЛК ТЭ). Для удобства ознакомления со всем корпусом материала рассматриваемые сравнительные конструкции воспроизводятся вместе с контекстами в Приложении к статье в виде словника.

Собиратели диалектной лексики нередко «обходят» подобные номинации своим вниманием ввиду их «сомнительного» языкового статуса, а лексикографы по той же причине не включают в словари. Сомнения относительно языкового (а не речевого) статуса сравнительных оборотов с личным именем и адъектонимом, очевидно, связаны с тем, что при наличии единичной фиксации трудно определить степень их воспроизводимости в речи. Следует иметь в виду и то, что степень идиоматичности подобных сравнительных конструкций минимальна; Е. С. Коган рассматривает их появление как первый этап становления фразеологизма [Коган 2014: 123]. Об идиоматичности атрибутивных сочетаний, связанных с конкретным носителем имени, в сравнении с теми, которые такого прецедента под собой не имеют, пишет и Е. Л. Березович [2012: 41-42].

\section{1. Структура сравнительных оборотов с личным именем и адъектонимом}

Структура таких языковых единиц предполагает наличие предиката высказывания, субъекта и объекта сравнения (соответственно - тот, с кем сравнивают, и тот, кого сравнивают и кто является субъектом действия). Однако предикат вследствие большой его вариативности непосредственно в состав устойчивых сочетаний, как правило, не включают (равно как и объект сравнения, что само собой разумеется). Ср., например: (нарядиться) (как) Анисья кли́мовская 'о человеке, вычурно одетом': «Оденешься, что видят, что что-то не так, так говорят: "Что нарядился, как Анисья климовская?!”»; «Жила какаято Анисья, плохо одевалась. Вот и говорят сейчас о плохо одетой женщине: “Анисья климовская идёт"» (Парф.).

Сравнение чаще всего выражено эксплицитно, с помощью союза как или что, но возможна 
и его импликация. Одно и то же устойчивое сочетание может быть употреблено с разными союзами, с каким-либо одним союзом и / или без него. Ср. (как) Павла годо́вская 'о человеке, который кричит, ругается' (Вохом.); как Ваня дудинский 'о человеке с лохматыми, длинными волосами и в рваной одежде', вырядиться что Ваня дуди́нский 'об одетом в рваную одежду человеке' (СППП: 89); ходить как Миша сла́вский 'о грязном, плохо одетом, неухоженном человеке', обрасти что Миша сла́вский 'об очень заросшем, бородатом и лохматом человеке' (там же: 105). В случае отсутствия союза на наличие сравнения в пресуппозиции может указывать антропоним, называющий субъекта сравнения, и / или свидетельства информантов (см. пример выше).

Антропоним представляет собой сочетание личного имени с оттопонимическим прилагательным или только личное имя. Ср. с приведенными выше: с Нинку-Серафимку 'о человеке невысокого роста с плотным телосложением': «Он маленький, как говорят, с Нинку-Серафимку. Была у нас Нинка-Серафимка, маленькая и толстенькая» (Павин.); как немытая Орина (Орина немытая) 'о грязном, неопрятном человеке': «Ну, говорят, как немытая Орина, всё время как Орина немытая. Была женшшина такая грязная, она на речку не ходила, худо умывалася, как, говорят, Орина немытая» (Вохом.).

Личное имя чаще употребляется в уменьшительной или уменьшительно-пренебрежительной форме, что соответствует неофициальному стилю речевой коммуникации диалектоносителей. См. также: не манилко, а ко́ржинский Данилко 'о человеке маленького роста' (Павин.); как Перша (ипа́тьевский) 'о неопрятном, неухоженном человеке' (Вохом.) (Перша < Перфилий); как Нинка дёменская 'о глупой женщине' (Буйск.); как Стёпка ма́словский 'о глупом человеке' (Буйск.). Одно имя встречается и в полной, и в краткой форме: Павлинья годо́вска(я) 'о неопрятной женщине' (Окт.); как Павлинья годо́в$c \kappa a(я)$ 'о непричесанной женщине' (Окт.) и (как) Павла годо́вская 'о человеке, который кричит, ругается’ (Вохом.).

Особо следует сказать об антропониме в составе устойчивого выражения разблажиться как Сидорка тя́пнинский 'о вспыльчивом человеке’ (Парф.). В данном случае это «замаскировавшееся» под личное имя отфамильное прозвище: «Говорят: “Разблажился как Сидорка тяпнинский”. Он жил в этом Тяпневе, очень по характеру был горячий, а фамилия была Cuдоров. Так говорят, когда горячий, когда вспыльчивый, из рамок человек».

Адъектоним, как правило, находится в постпозиции к личному имени, что соответствует «прозвищной» модели антропономинации (подробнее ниже). См., однако, не Манилко, а ко́ржинский Данилко 'о человеке маленького роста' (Павин.), где препозиция оттопонимического прилагательного обусловлена просодикой фразеологизма (его ритмом и рифмовкой логически противопоставленных друг другу именных компонентов).

Оттопонимическое прилагательное в подавляющем большинстве случаев образуется с помощью суффикса -cк-, который реализует идею отношения к топониму как к производящей основе. Зафиксировано только одно прилагательное ипа́тьевский с суффиксом -евск-, образованное от топонима Ипатовщчина. В качестве основы выступают региональные ойконимы (названия населенных пунктов сельской местности): (как) Саня пе́номская < Пе́нома, д. (Вохом.); как Дуня каси́мовская < Каси́мово, д. (Вохом.) и др. Во многих случаях топоним присутствует в контексте, что позволяет легко восстановить его форму: «Вот, скажут, что ты как Дуня касимовская ходишь! Дуня-то эта жила на Касимове, она очень красивая была, умная, а потом ей родители запретили замуж выйти за её любимого, так она и с ума сошла. Старая уж стала, а всё оденется в блузки нарядные, юбки и бантик себе на голову приделает, всё думает, что она красивая». Не исключено, что именно оттопонимическое прилагательное, употребленное в сравнительном обороте вместе с личным именем, является одним из стимулов для порождения мотивационного контекста с указанием местного ойконима.

Иногда информант при пояснении словосочетания использует сокращенный или неофициальный вариант названия населенного пункта, что требует обращения к карте местности и топонимическим материалам: «У нас Федя был такой, немножко вот такой парень. У нас был такой дурачок и из-за этого все говорят: “Ну, как Федя". “Ой, - говорят, - как Федя парюгско́й”. На Па́рюге он был-то». Скорее всего, речь идет о д. Малый Парюг Вохомского района Костромской области, которая находится в девяти километрах к юго-востоку от д. Тихон, где и был записан контекст.

Е. Л. Березович обращает внимание на то, что поиск производящей для адъектонима основы может быть затруднен наличием омонимов, которые в узколокальной топосистеме встречаются чаще, чем среди макротопонимов [Березович 2012: 34]. См. приводимый ею пример: перм. (как) Максим опали́шенский 'о неряшливо одетом человеке' (ФСПГ: 207). Согласно автору, деревень Опалишино или Опалиха в Оханском районе Пермской области, где было записано это устойчивое выражение, в настоящее время нет. 
Деревни с названием Опалиха фиксируются в районах, которые не граничат с Оханским, - Нытвенском и Частинском; есть также д. Верхняя Опалиха в Кишертском районе. Углубленные поиски дают бывшую д. Опалиха в Оханском районе; она была снята с учета в 1964-1969 гг. Скорее всего, это название и легло, по мнению Е. Л. Березович, в основу номинации. Данный пример, на наш взгляд, указывает на еще один фактор демотивации оттопонимического прилагательного - забвение производящей для него основы.

Формула именования одного и того же лица (одно- или двухкомпонентная) может варьировать: см., в частности, выше как Федя (парюгско́й) 'о сумасшедшем человеке'. Следует отметить, что в каких-то случаях рассматриваемая атрибутивная конструкция может сворачиваться до сравнения с личным именем, и тогда оттопонимическое прилагательное становится факультативным элементом словосочетания: как Перша (ипа́тьевский) 'о неопрятном, неухоженном человеке' (Вохом.): «Я его уже не застала, я пришла, Першы-то не было. Это не у нас, это в другой деревне. ...Этот Перша жил на Ипатовщине, дак это я вот пришла дак слыхала, что он колдовал якобы, этот Перша, но я его и не видала, видно, умер он до меня. Его Перфил звали, Перфилий, а в деревне уж Перша да Перша. Помню, мамаша говорила, им потыка́лися всё: "Ну, как Перша". Это и мамаша часто употребляла. Он и грязный, и неухоженный, он жил один, наверное. В деревне потыка́лись: “Как Перша"»; «Он [деверь] придёт весь грязный, мамаша и говорит: "Ну, как Перша ипатьевский, пришел весь грязный”».

В рамках настоящей статьи мы ограничимся рассмотрением только тех антропонимов, в состав которых входит оттопонимическое прилагательное в качестве постоянного или факультативного компонента (о некоторых из них мы писали ранее, см.: [Феоктистова 2012: 259-260]).

\section{2. Семантика сравнительных оборотов с личным именем и адъектонимом}

От анализа структуры сравнительных конструкций перейдем к рассмотрению их семантики - тому, как они распределяются по тематическим сферам и какими системными отношениями связаны друг с другом.

Зафиксированные на территории нескольких районов Костромской области устойчивые сочетания с личным именем и оттопонимическим прилагательным входят в следующие тематические рубрики (отдельные примеры по другим территориям приводятся в статье Е. Л. Березович [2012: 41-42]): а) внешний вид (5) $)^{4}$ не манилко, а ко́ржсинский Данилко 'о человеке маленького роста' (Павин.); (нарядиться) как Анисья кли́мовская 'о человеке, вычурно одетом' (Парф.); Анисья кли́мовская 'о странно одетой женщине' (Парф.); как Дуня каси́мовская 'о нелепо одетом человеке (женщине)' (Вохом.); как Павлиная годо́вска(я) 'о непричесанной женщине' (Окт.); Павлинья годо́вска(я) 'о неопрятной женщине' (Окт.); как Периа (ипа́тьевский) 'о неопрятном, неухоженном человеке' (Вохом.);

б) интеллектуальные способности (4): как Дуня каси́мовская 'о ненормальном человеке' (Вохом.); как Нинка дёменская 'о глупой женщине' (Буйск.); как Стёпка ма́словский 'о глупом человеке' (Буйск.); как Федя (парюгской) 'о сумасшедшем человеке' (Вохом.); Яким са́ловский 'простак, простофиля' (Макар.);

в) двигательная активность (1): как Саня тага́нская сидеть 'не сидеть на месте, ёрзать' (Окт.);

г) поведение в социуме (4): (как) Павла годо́вская 'о человеке, который кричит, ругается' (Вохом.); разблажиться как Сидорка тяпнинский 'о вспыльчивом человеке' (Парф.); как Аля парюгска́я 'о женщине, которая долго не выходит замуж' (Вохом.); как Саня пе́номская 'о женщине, живущей вдали от других людей’ (Вохом.).

С учетом общего небольшого количества устойчивых сочетаний рассматриваемого типа количественное преобладание тех сравнительных оборотов, которые описывают внешность человека, над остальными несущественно - важнее то, что все репрезентируемые данными оборотами идеограммы весьма характерны для отантропонимической номинации. Ср. «рейтинг» идеограмм по их заполняемости апеллятивными производными от личных имен, составленный И. В. Родионовой [2005: 178-179] $]^{5}$.

В списке из 13 позиций на первом месте «умственные способности», на четвертом - «поведение в общении», на седьмом - «внешний вид, опрятность», на восьмом - «подвижность, физическая активность, ловкость». Наибольшее число номинаций в каждой тематической рубрике, составляющих таким образом ядро (9-10 и более деантропонимов) или среднюю зону (5-8 деантропонимов) соответствующего семантического поля, обозначают то или иное отклонение от нормы:

- «умственные способности»: 'дурак' и др. (ядерная зона поля);

- «поведение в общении»: 'забияка, драчун, хулиган' и др. (средняя зона; ядро поля деантропонимами не представлено);

- «внешний вид, опрятность»: 'неряшливый, неопрятный' (ядерная зона); примечательно, что 
значение 'плохо (неуместно, неприлично) одетый’ тоже фиксируется, но находится на периферии поля (четыре и менее деантропонимов);

- «подвижность, физическая активность, ловкость»: 'подвижный, беспокойный, суетливый' (средняя зона; ядро - 'неуклюжий, медлительный, вялый') [Родионова: 2005: 178-179].

В приведенном И. В. Родионовой языковом материале нет примеров, подобных костр. как Аля парюгска́я 'о женщине, которая долго не выходит замуж' и как Саня пе́номская 'о женщине, живущей вдали от других людей’ (Вохом.). Это, наверное, можно расценивать как свидетельство потенциально более широкого, чем для «невоплощенных» (т. е. не имеющих конкретнореферентной отнесенности) имен, спектра идеограмм, которые могут быть представлены именами «воплощенными» 6 .

Эти две номинации любопытны еще и с точки зрения системных отношений, также возможных для подобных наименований. См.: «Аля парюгская ещё у нас была, Саня пеномская. Вот выражения-ти наши. Ну, говорят, как Аля парюгская, как Саня пеномская». Системные отношения выстраиваются не только на синхронном уровне, когда употребление в речи одного сравнительного оборота влечет за собой упоминание другого, но и на диахронном, когда наличие одного служит основой для создания другого.

В целом, анализ семантики устойчивых сочетаний личного имени с адъектонимом показывает, что данному типу номинаций, как и следовало ожидать, присущи те же семантические особенности, что и одиночным деантропонимам: доминанта негативного (преобладание отрицательной характеристики человека по какомулибо параметру), полисемия и / или диффузность значения (см. о них подробнее: [там же: 176-180]). О двух последних стоит сказать подробнее.

Согласно И. В. Родионовой, в рамках исследуемого ею семантического поля деантропонимов довольно распространено явление, «когда одно имя фиксируется в качестве обозначения различных качеств характера (полисемия) либо когда значение, сформулированное в источнике весьма комплексно, касается ряда черт характера, так что номинация может быть представлена в двух-трех идеограммах (диффузность)» [там же: 180]. См. в нашем материале:

- «диффузность» или, точнее, комплексность семантики: как Дуня каси́мовская 'о ненормальном человеке' и 'о нелепо одетой женщине' (Вохом.). Оба этих значения представляют связанные друг с другом характеристики: манера одеваться носительницы имени выдает ее интеллектуальную неполноценность;
- полисемия: как Павлинья годо́вска(я) 'о непричесанной женщине', Павлинья годо́вска(я) 'о неопрятной женщине' (Окт.) и (как) Павла годо́вская 'о человеке, который кричит, ругается' (Вохом.). Оттопонимическое прилагательное отсылает к названию деревни Годовка в Октябрьском районе Костромской области, распространение сравнительного оборота на соседней территории сопровождается переосмыслением его «внутренней формы» и значения (см. подробнее ниже).

В дополнение к названным семантическим особенностям деантропонимов можно указать экспрессивность их семантики, которая складывается за счет обозначения антинормы, а также прецедентного характера номинации (последнее только при условии, что деантропоним не утратил своей мотивированности). Ср. высказывание Е. Л. Березович, относящееся к устойчивым сочетаниям с личным именем и оттопонимическим прилагательным: «шутка становится острее, если объект вышучивания - не какой-то неизвестный стёпа или яким, а представитель соседней деревни» [Березович 2012: 43].

\section{3. Семантика, функции и ономастический статус оттопонимического прилагательного в составе сравнительной конструкции с личным именем}

Отдельного рассмотрения заслуживают смысловая нагрузка и функции оттопонимического прилагательного в составе сравнительных оборотов с личным именем.

Следует отметить, что в целом сочетаемостный потенциал адъектонимов чрезвычайно высок: они могут соседствовать практически с любым существительным. Оказываясь в составе устойчивых адъективных сочетаний, оттопонимические прилагательные стремятся к апеллятивизации и наряду с нейтральным «географическим» значением развивают оценочную характеризующую семантику, нередко значительно отстоящую от генетического геолокационного значения. Достаточно сравнить семантику одного и того же адъектонима в разных словосочетаниях, чтобы увидеть, как может ослабевать связь с производящим топонимом. Ср.: 1.московское метро, 2. московская водка 'название сорта водки' (ПОС 18: 379) и 3. московский гриб 'белый гриб, боровик' (СРГМорд А-Г: 128). В первом примере связь с топонимом Москва максимальна; во втором случае она уже слабее: водка этого сорта может быть изготовлена не только в Москве; в третьем словосочетании оттопонимическое прилагательное развивает значение 'самый лучший, благородный': связь с производящим топонимом здесь уже опосредованна и 
ощущается через сему 'столичный = самый лучший'.

Анализируя сравнительные конструкции с личным именем и адъектонимом, необходимо в первую очередь выяснить, входит ли оттопонимическое прилагательное в состав устойчивого сочетания как часть сложного антропонима или же добавляется к личному имени в процессе вторичной номинации.

С одной стороны, атрибутивное сочетание, состоящее из личного имени и оттопонимического прилагательного, является одной из принятых антропонимических формул. С другой стороны, следует учитывать, что подобная номинация не только может носить «прозвищный» характер, но и быть ситуативным наименованием человека в определенных условиях речевой коммуникации. Адъектоним прежде всего выполняет уточняющую функцию, которая оказывается востребованной при несовпадении места жительства участников речевой ситуации (ситуации номинации) или незнании адресатом объекта речи (тогда географическая «привязка» личного имени как бы восполняет его информативную «ущербность»). Ср., к примеру, следующее высказывание информанта: «Тёща рассказывала, на трактоpe всех повезли, а одну оставили. Так вот тёща кричит трактористу: “Стой! Мильку зашильскую забыли!”» (Буйск.).

Однако установить языковой или речевой характер подобных номинаций в составе устойчивого сочетания по имеющимся данным не представляется возможным. Этого не позволяет сделать ни иллюстративный контекст, ни запись прозвища как такового (в данном случае считаем возможным употребление этого термина, имея в виду, что характеризующая функция прозвища заключается в геолокации носителя имени).

В информационно-поисковой системе «Русский традиционный ономастикон: антропонимия, зоонимия, астронимия» (РТО), которая в том числе содержит индивидуальные прозвища, собранные участниками ТЭ УрФУ, нашлось только четыре личных имени в сочетании с оттопонимическим прилагательным из тринадцати встретившихся в сравнительных конструкциях (Аля Парюгска́я, Анисья Кли́мовская, Дуня Каси́мовская, Федя Парюгско́й). При этом доподлинно неизвестно, были ли записаны эти атрибутивные сочетания как прозвища или же они были извлечены из контекста, содержащего сравнительный оборот.

В материалах ЛК ТЭ обращает на себя внимание разнобой в написании личного имени и адъектонима в составе устойчивого сочетания, что отражает сомнения собирателя по поводу их ономастического статуса. Ср., к примеру:
1. «Про человека говорят - Павла Годовская. Это если кричит громко человек. Это на Вятке в Годовке жила Павла. Вот про неё и тут говорят: "Ну, чего ты как Павла Годовская!"»; 2. «Ходишь как павлинья годовская. Распустишь волосы, ходишь непричёсанная, как росомаха» 7 . Однако написание с прописной буквы преобладают, т. е. «среднестатистический» собиратель воспринимает пару «личное имя + адъектоним» в сравнительной конструкции скорее как сложный антропоним. Это восприятие зависит также от иллюстративного контекста, позволяющего судить о степени мотивированности сравнительного оборота в сознании не только собирателя, но и диалектносителя. В первом из приведенных контекстов упоминается носитель имени, образ которого лег в основу сравнения, поэтому и в функции сравнения антропоним пишется с прописной буквы (Павла Годовская). Во втором примере внутренняя форма отпрецедентной номинации непрозрачна и оба ее компонента написаны со строчной буквы (павлинья годовская).

Таким образом, при анализе семантики личного имени и адъектонима в рамках сравнительной конструкции мы учитываем обе рассмотренные возможности - включение оттопонимического прилагательного в устойчивое сочетание в составе сложного антропонима (прозвища) и отдельно от антропонима, который в таком случае будет представлен только личным именем. Тем не менее в целях унификации мы предпочли прописное написание личного имени и строчное - оттопонимического прилагательного, подчеркивающее его промежуточное положение между онимом и апеллятивом.

Условия контекста могут быть таковы, что делают возможным употребление антропонима обобщенно, для обозначения чем-то похожего на «владельца» имени человека. См., например: «В той стороне были деревни Ду́лово, Лемехо́во. И вот говорю: ну, дура лемяховская, дурочка лемяховская! (...) А Шуры нет уже, царство ей небесное. Шура-дура всё звали. Шура-дура из Лемехово. Ой, дура лемеховская. Я помню, Гриша был, Аннушка была... Они такие были немножко вроде Володи, похожи на ружьё. И когда Тамара назвала Гришей, я думаю: почему Вовку-то всё в молодости Гриша звали, у него прозвище Гриша. И мне представляется вот этот Грима лемехо́вский. Гриша этот дурачок был, он пас овец. Шура была такая простая. Долго замуж не выходила» (Буйск.).

Это как раз то, что можно было бы, вслед за Е. Л. Березович, назвать «нулевой» ступенью семантической деривации имени - «нет изменения референциальной базы значения, для такого изменения только создаются предпосылки» 
[Березович 2018: 16] ${ }^{8}$. Однако в составе сравнительного оборота такие изменения уже налицо: носитель имени выступает не во всей совокупности присущих ему черт, а как некий «эталонный» представитель какой-либо одной черты. Соответственно, антропоним в данной ситуации приобретает функцию номинации-характеристики (см. об этом также: [Родионова 2005: 183184]). Таким образом, появление подобных конструкций можно рассматривать не только как первую стадию фразеообразования (см.: [Коган 2014: 123]), но и как первую ступень семантической деривации и апеллятивизации антропонима (личного имени не только в сочетании с оттопонимическим прилагательным, но и самого по себе).

В то же время тесная связь адъектонима с производящей основой и его возможное факультативное положение во фразеологизме - см. выше как Периа (ипа́тьевский), как Федя (парюгско́й) - свидетельствуют скорее о том, что в большей степени смысловой трансформации подвергается личное имя. Основная же функция адъектонима в составе фразеологического оборота - соотнесение определяемого предмета (в данном случае - носителя имени) с географическим объектом (местом жительства). В случае отсутствия сравнительного союза именно оттопоническое прилагательное может указывать на то, что в основе номинации лежит сопоставление с реальным носителем «воплощенного» личного имени (а не языковые и/или текстовые коннотации, присущие имени «невоплощенному»).

Сохранение адъектонимом своего топографического значения не исключает наличия у него каких-либо коннотаций, но эти коннотации «наследуются» им от производящего топонима. См. приводившийся выше контекст: «Про человека говорим Павла годовская. Это если кричит громко человек. Это на Вятке в Годовке жила Павла. Вот про неё и тут говорят: “Ну, чего ты как Павла годовская!"». Примечательно, что в контексте встречается топоним Вятка, обозначающий местность, где, по мнению информанта, находится д. Годовка. Разумеется, речь идет не о городе Кирове и даже не о Вятском регионе, а об Октябрьском районе Костромской области, который в сознании жителей Вохомского района и определяется как вятский, так как граничит на юго-востоке с Кировской областью (подробнее об этом «смещении вятских границ» см.: [Казакова 2011: 27-28]). Упоминание Вятки позволяет не только верно «привязать» Павлу годовскую к нужной д. Годовка, но и «подкрепить» географическую семантику адъектонима характеризующей «вятской». Жители Вохомского района называют жителей Октябрьского вятченёнками- синепупиками и воспринимают их как людей чужих, говорящих иначе (см.: [там же: 40-41]). В число таких вятченёнков, очевидно, попадает и Павла годовская, которая кричит и ругается 9 .

Дополнительными коннотациями адъектоним наделяется и тогда, когда образован от квазитопонима. Ср.: Иён заболотский 'о придурковатом человеке': «Это кто такой? Иён заболотской! Раньше у нас старичок такой был, по деревням ходил, он был немножко не в себе» (Шар.). Скорее всего, прилагательное заболотский генетически не связано с ойконимом и не столько отвечает за геолокацию объекта, сколько за оценочную характеристику, подчеркивая, что Иён не в себе еще и потому, что появился из неизвестного места за болотом. В другом случае прилагательное валявкинские, которое по форме напоминает адъектоним, характеризует мужиков с. Ильинское Парфеньевского района Костромской области как ленивых, ср. костр. валявка 'ленивый человек' (ЛК ТЭ).

В целом, следует отметить, что личное имя и адъектоним поддерживают ономастический статус друг друга, оказавшись в составе фразеологического оборота.

Отсутствие или редукция атрибутирующего прилагательного, соответственно, ослабляют статус личного имени и сообщают ему деантропонимическое «ускорение», подталкивая к дальнейшей семантической деривации. Ср., например, костр. (как) евло́га 'бродяга', 'плохо ходящий человек', 'слабоумный человек', 'лентяй', 'пьяница' (Вохом.), как у Евлоги 'о человеке, имеющем при себе много каких-либо вещей, предметов’: «Видишь, сколько бумаг - как у Евлоги. Это мужик у нас был “не все дома”, Евлога» (Окт.). Образ нищего, к которому восходят данные номинации, постепенно стирается: «Евлога - дак это прозвище у человека, по-моему. Ленивых называли, как, говорят, евлога. А кто такой? Ну, говорят, евлога. Евлога, наверно, мужчина был, лентяй»; имя же становится нарицательным: «Бездомные такие, ходят как евлоги - оно и сейчас встречается» (показательна и форма множественного числа деантропонима $)^{10}$.

Вместе с тем иногда и при наличии адъектонима в составе устойчивого сочетания бывает затруднительно разграничить личное имя первой и последующих ступеней деривации. Если один и тот же деантропоним употребляется самостоятельно и в сочетании с оттопонимическим прилагательным, но на разных территориях, то можно предположить омонимию исходных «воплощенных» личных имен либо образование фразеологического сочетания из апеллятивного деривата личного имени и адъектонима. См. примеры Е. Л. Березович [2012: 42]: перм. как мала- 
нья копьло́вская 'о забывчивом человеке' (ФСПГ) - ср. свердл. маланья 'простушка; глуповатая, недалёкая женщина, которую легко одурачить, обмануть' (СРНГ 17: 318) и др.; яросл. стёпа сущо́вский 'о неумелом, нерасторопном человеке' (ЯОС 9: 73) - ср. арх. стёпа 'неумелый, неловкий человек' (КСГРС). Если же территория одна, установить направление деривации - от апеллятивного производного личного имени или от подвергшегося деонимизации антропонима в составе устойчивого выражения практически невозможно. Ср.: костр. Яким са́ловский 'простак, простофиля' и яким 'необразованный человек, глупец’ (Макар.); влг. Папи́ло фи́линский 'о бестолковом, беспутном человеке' и папи́ло 'то же' (СРГК 4: 391), от имени Папи́л (церк. Папила, нар. Папи́ло) [Березович 2012: 42].

Этот ряд примеров можно дополнить:

- пск. Филя тобольский 'о несообразительном, рассеянном человеке’ (СППП: 77) - ср. диал. филя 'простофиля, простак, разиня, недоумок' (Даль 4: 535), от имени Филя (уменьш. к Филат, Филимон, Филипn) (Фасмер 4: 195); подробнее о коннотациях данного имени см.: [Виноградов 1994: 578-581];

- влг. Пантелей чистодо́рский 'бранно': «Сын-то пестерь такой, ничего делать не хочет, пьет только, пантелей чистодорский»; «Баба его обругала: ой, ты, пантелей чистодорский»; «Накричит: ой ты, пантелей чистодорский, взрослым-то подражает» (СРГК 4: 390). Ср., к примеру, курган., кемер. новосиб., амур. пантюха 'о нерасторопном, глуповатом, необразованном человеке' («Муж пантюха такой, не работной человек, не добиться нигде ничего, у него в руках ничего не держится»; «А пантюха и чечас пантюха, значит, ни с чем пирожок, беспонятный») (СРНГ 25: 200) $)^{11}$.

Употребление в составе атрибутивных конструкций апеллятивных производных от личных имен, не связанных с местными «прототипами», а также прилагательных, которые образованы от квазитопонимов, ведет к частичной онимизации данных компонентов. Это сопровождается изменением их смысловой и функциональной нагрузки в составе фразеологизмов. Добавление к апеллятиву топонимического определения, по мнению Е. Л. Березович [2012: 42], придает сочетанию иллюзию «достоверности» (рисуемый образ как бы обретает черты реального персонажа) и усиливает его экспрессивность (см. об этом выше).

\section{Выводы}

Анализ функционирующих в костромских говорах сравнительных конструкций с личным именем и оттопонимическим прилагательным позволяет в самом общем виде охарактеризовать модель номинации, представленную подобными устойчивыми сочетаниями. Данная модель географически отнюдь не уникальна, о чем свидетельствуют спорадически фиксируемые на других территориях языковые факты.

Устойчивые выражения этого типа довольно вариативны по своему составу. Облигаторным компонентом словосочетания является только антропоним, обозначающий объект сравнения человека, который по тем или иным параметрам не соответствует нормам деревенского сообщества (отмечаются отклонения во внешнем виде, интеллектуальной деятельности, двигательной активности и социальном поведении). Остальные же компоненты - сравнительный союз (как или что) и глагольный предикат - факультативны; может быть опущено и оттопонимическое прилагательное, которое в составе антропонимической формулы занимает постпозицию по отношению к личному имени. Открытым остается вопрос, следует ли считать личное имя и адъектоним элементами сложного антропонима или же оттопонимическое прилагательное присоединяется к личному имени уже на этапе семантической деривации при включении в состав сравнительной конструкции.

Несмотря на подвижность лексического состава, рассматриваемые словосочетания могут быть признаны фразеологическими, поскольку обладают устойчивостью, т. е. регулярно воспроизводятся в речи, и - главное - идиоматичностью. Степень идиоматичности фразеологизма в данном случае будет зависеть от знания или незнания адресатом речи объекта сравнения. Личное имя в составе сравнительного оборота приобретает функцию номинации-характеристики, обозначая референта имени как «эталонного» носителя каких-либо отрицательных свойств или форм поведения.

Наряду с именем, отсылающим к реальному носителю, в составе сравнения могут встречаться мнимые антропонимы, ономастический статус которых не очевиден. Однако в количественном отношении преобладают «воплощенные» имена, имеющие конкретно-референтную отнесенность, и набор идеограмм для них потенциально шире, нежели для «невоплощенных» имен.

В сочетании с адъектонимом личное имя реализует тот же семантико-деривационный потенциал, что и без него. Об этом свидетельствует совпадение перечня идеограмм и наличие ряда общих семантических черт для тех и других деантропонимов: доминанта негативного (преобладание отрицательной характеристики человека по какому-либо параметру), полисемия и/или диффузность значения, а также экспрессивность. Функция оттопонимического прилагательного в 
составе антропонимической формулы - территориальная «привязка» имени и его носителя. Присутствие адъектонима в составе сравнения укрепляет ономастический статус антропонима, напоминая о том, что в основе номинации лежит сопоставление с реальным носителем имени. Оказавшись без адъектонима, личное имя быстрее теряет связь с единичным объектом и в большей степени подвергается апеллятивизации.

Представленная модель прецедентной номинации нетривиальна тем, что позволяет увидеть не столько результат семантической деривации онимов, сколько динамичный процесс деонимизации языковых единиц.

\section{Примечания}

${ }^{1}$ Исследование выполнено в рамках гранта РНФ «Контактные и генетические связи севернорусской лексики и ономастики» (проект 17-1801351). Авторы искренне благодарны Е. Л. Березович за предложенную тему публикации.

${ }^{2}$ В отечественной лингвистике для обозначения этого производного используются следующие термины: прилагательное от географического названия [Левашов 1986], ойконимическое прилагательное, оттопонимическое прилагательное [Генералова 2016], адъектоним [Озтюрк 2018] - два последних являются «рабочими» и в настоящей статье.

${ }^{3}$ Здесь и далее материалы лексической картотеки Топонимической экспедиции УрФУ не паспортизируются; в круглых же скобках указывается административный район Костромской области, на территории которого было зафиксирован тот или иной языковой факт: Буйск. - Буйский, Вохом. - Вохомский, Макар. - Макарьевский, Окт. - Октябрьский, Павин. - Павинский, Парф. - Парфеньевский, Шар. - Шарьинский.

${ }^{4} \mathrm{C}$ учетом «диффузности» или комплексности семантики сравнительных оборотов (см. подробнее ниже) в скобках указывается число языковых единиц, а не репрезентируемых ими идеограмм (лексических значений), если эти идеограммы (значения) относятся к одной тематической группе.

${ }^{5}$ Автор рассматривает и устойчивые сочетания с личными именами и адъектонимами, отмечая их периферийное положение в рамках полевой структуры, которую образуют деантропонимы - характеристики человека. «...Здесь отступления от первичной функции антропонима минимальны: сохраняя сигнификативную сему единичности, имя на основе механизма сравнения - ср. частотность вхождения компонента как в состав номинативного оборота - отсылает к образу конкретной личности носителя данного имени» [Родионова 2005: 184]. Следует учиты- вать и то, что атрибутивных сочетаний значительно меньше, чем апеллятивных производных от одиночных личных имен.

${ }^{6} \mathrm{O}$ терминах «воплощенное / невоплощенное имя» «актуальный» / «потенциальный (виртуальный) антропоним» и др. см.: [Смольников 2005].

${ }^{7}$ Согласно современной норме правописания прилагательные, образованные от географических названий (если они не являются частью составного названия), пишутся со строчной буквы (невские берега). Если же они входят в состав сложных индивидуальных названий людей (в нашем случае в состав прозвища), то писать их следует с прописной (Дмитрий Донской) (см.: [Лопатин 2011: 150-154]).

${ }^{8}$ Е. Л. Березович рассуждает о «нулевой ступени» деривации применительно к другому классу имен собственных - катойконимам - в случае обретения ими характеризующей (в том числе оценочной) семантики в узком или широком контексте, а также благодаря различным фонетическим, словообразовательным или лексическим преобразованиям. Например: «Великодворяна, что с них взять!» (жители куста деревень Великодворье в Тотемском районе Вологодской области); настоящий уралец, коренной москвич; тамбовцы (при аттракции к овцыь) вместо тамбовчане, влг. бандеровщь 'жители д. Байдарово Никольского района Вологодской области' [Березович 2018: 14-16]. Однако, следуя заданным критериям разграничения ступеней деривации («изменение референциального значения»), эти примеры логичнее было бы, на наш взгляд, отнести не к «нулевой», а к первой ступени деривации.

${ }_{9}^{9}$ Адъектоним может приобретать коннотации, отражающие стереотипные представления о жителях определенной местности, в сочетаниях с апеллятивом. Ср.: рус. ленив, как кле́пенский мужик 'о лентяе, полном бездельнике' (Смолен. губ., Сычевск. уезда, село Клепени, где все нищие, по обычаю) (Даль ПРН 2 2: 51): предполагается, что все клепенские мужики - лентяи. Столь же коннотативно нагруженным оказывается оттопонимическое прилагательное в составе коллективного прозвища, хотя здесь оно занимает факультативное положение. Ср., к примеру, завражные заводиль 'жители с. Завражье Кадыйского р-на Костромской обл.' («Мы-то окаем, а оне заводят, вот и зовут их завражные заводилы»); (клима́тинские) паньь 'жители д. Климатино Солигаличского р-на Костромской обл.' [Воронцова 119]; (чиво́чинские) сапожники 'жители б. д. Чивочи Октябрьского р-на Костромской обл.' (ЛК ТЭ).

${ }^{10}$ Возможно, забвению образа носителя имени способствовало распространение деантропонима на территории граничащего с Вохомским Ок- 
тябрьского района, на территории которого его еще помнят, хотя нищие бродяги, как и их имена, четкой географической «привязки» обычно не имеют.

11 Ж. Ж. Варбот включает лексему пантюха в одно морфосемантическое поле со словом пентюх, для которого также не исключена возможность вторичной паронимической аттракции с именем Пантелеймон (ее просторечной формы Пентелеймон, распространенной преимущественно в низших социальных слоях) [Варбот 2011: 343-344, 338, 568].

\section{Приложение}

\section{Сравнительные конструкции}

с личным именем и адъектонимом в говорах Костромской области под данным [ЛК ТЭ]

Устойчивые сочетания приводятся по опорному слову - личному имени, но сам антропоним при этом не дублируется, за исключением тех случаев, когда во фразеологизме личному имени предшествует оттопонимическое прилагательное (см. *ДАНИЛКО КО́РЖИНСКИЙ: НЕ МАНИЛКО, А КО́РЖИНСКИЙ ДАНИЛКО). Опорные слова выделены полужирным шрифтом и размещаются в алфавитном порядке. За толкованием значения фразеологизма следует сокращенное указание на административный район Костромской области, в котором был он записан; контекстные иллюстрации снабжены указанием на населенный пункт и сельскую администрацию этого района. В конце словарной статьи после знака $\boldsymbol{\Delta}$ дается название, послужившее производящей основой для адъектонима в составе сравнительной конструкции, указание на вид объекта (и также район, в случае несовпадения с районом фиксации фразеологизма).

КАК АЛЯ ПАРЮГСКА́Я. О женщине, которая долго не выходит замуж (Вохом.). «А Аля парюгская на Парюге жила одна. Она замуж не выходила, ничего, эдак вот и скажут: “Как Аля парюгская, замуж не можешь выйти”»; «Аля парюгская ещё у нас была, Саня пеномская. Вот выражения-ти наши. Ну, говорят, как Аля парюгская, как Саня пеномская. А Саня пеномская жила очень долго одна в деревне на Пеноме, в лесу. Деревня уж стала зарастать, она всё жила, потом сюда выехала. Вот где чего одиноко живёт человек, вот я на самом конце деревни, мне Валя часто: “Ну, ты как Саня пеномская! Живешь гдето на хуторе"» (с. Тихон, Тихоновская с/адм).

А Малый Па́рюг, д.

(НАРЯДИТЬСЯ) КАК АНИСБЯ КЛЙМОВСКАЯ. О человеке, вычурно одетом (Парф.). «Как Анисья климовская - то ли что повязала не так. Деревня была Климовское, двенадцать до- мов было. (...) У ей родители померли, три брата, а она одна осталась. Она сроду была неумная, ну слабоумная. Она могла юбку на юбку надеть, бантов навяжет, гребёнок навтыкать. Оденешься, что видят, что что-то не так, так говорят: “Что нарядился, как Анисья климовская?!”»; «Жила какая-то Анисья, плохо одевалась. Вот и говорят сейчас о плохо одетой женщине: “Анисья климовская идёт”» (д. Никулино, Ширская с/адм). А Клймовское, д.

*ДАНИЛКО КО́РЖИНСКИЙ: НЕ МАНИЛКО, А КО́РЖИНСКИЙ ДАНИЛКО. О человеке маленького роста (Пав.). «Идёт маленький человек, дак скажут: это не манилко, а коржинский Данилко. Был когда-то Данилко из деревни Коржино, он невысокий был, карлик» (д. Большой Завраг, Павинская с/адм). А Ко́ржино, д.

КАК ДУНЯ КАСЙМОВСКАЯ. 1. О нелепо одетом человеке (женщине) (Вохом.). «Ой, и красивая была, богатая, умная - Дуня-то касимовская, а как умом тронулась... совсем не та стала. Найдёт на неё что - оденется как капуста, одна из-под одной одежды торчит, всё выставляется. (...) Сейчас кто так оденется как она, так скажут, что ты как Дуня касимовская оделась» (д. Поспехово, Обуховская с/адм). 2. О ненормальном человеке (Вохом.). «Вот, скажут, что ты как Дуня касимовская ходишь! Дуня-то эта жила на Касимове, она очень красивая была, умная, а потом ей родители запретили замуж выйти за её любимого, так она и с ума сошла. Старая уж стала, а всё оденется в блузки нарядные, юбки и бантик себе на голову приделает, всё думает, что она красивая»; «У нас тут ещё одна ходила, как блаженная. Дуня касимовская. Вся юбка в пуговицах. Разные все и везде поподшиты. Ну и когда одета так, не пойми чего, говорят: “Ну, чего ты как Дуня касимовская!"» (пос. Малое Раменье, Малораменская с/адм). А Каси́мово, д.

(КАК) НИНКА ДЁМЕНСКАЯ. О глупой женщине, дурочке (Буйск.). «Нина была дёменская, деревня Деменково, вот говорили: “Чё ты как Нинка дёменская”. Сроду, она родилась такая дурочка» (с. Шушкодом, Шушкодомская с/адм). А Деменко́во, д.

(КАК) ПАВЛА ГОДО́ВСКАЯ. О человеке, который кричит, ругается (Вохом.). «Про человека говорят - Павла годовская. Это если кричит громко человек. Это на Вятке в Годовке жила Павла. Вот про неё и тут говорят: “Ну, чего ты как Павла годовская!” (пос. Масленниково, Семеновская с/адм). А Годо́вка, д. (Окт.).

(КАК) ПАВЛИНЬЯ ГОДО́ВСКА(Я). 1. КАК ПАВЛИНЬЯ ГОДО́ВСКА(Я). О непричесанной женщине (Окт.). «Ходишь как павлинья годовска. Распустишь волосы, ходишь непричёсанная, как росомаха» (с. Соловецкое, Соловецкая 
с/адм). 2. ПАВЛИНЬЯ ГОДО́ВСКА(Я). О неопрятной женщине (Окт.): «Ну, Павлинья годовска! Это выглядит плохо, неаккуратный. А уж какая была эта павлинья годовска - не знаю. На мужчину так не скажешь. "Павлин годовский” - так не говорили. А вот павлинья годовска - да, это про женщину говорили» (с. Соловецкое, Соловецкая с/адм). А Годо́вка, д. (Окт.).

КАК ПЕРША (ИПА́ТЬЕВСКИЙ). О неопрятном, неухоженном человеке (Вохом.). «Я его уже не застала, я пришла, Першы-то не было. Это не у нас, это в другой деревне. ...Этот Перша жил на Ипатовщине, дак это я вот пришла, дак слыхала, что он колдовал якобы, этот Перша, но я его и не видала, видно, умер он до меня. Его Перфил звали, Перфилий, а в деревне уж Перша да Перша. Помню, мамаша говорила, им потыка́лися всё: “Ну, как Перша”. Это и мамаша часто употребляла. Он и грязный, и неухоженный, он жил один, наверное. В деревне потыка́лись: “Как Перша"»; «Он [деверь] придёт весь грязный, мамаша и говорит: “Ну, как Перша ипатьевский, пришел весь грязный”» (д. Чучино, Сосновская с/адм). А Ипа́товщина, д.

КАК САНЯ ПЕ́НОМСКАЯ. О женщине, живущей вдали от других людей Вохом.). «Аля парюгская ещё у нас была, Саня пеномская. Вот выражения-ти наши. Ну, говорят, как Аля парюгская, как Саня пеномская. А Саня пеномская жила очень долго одна в деревне на Пеноме, в лесу. Деревня уж стала зарастать, она всё жила, потом сюда выехала. Вот где чего одиноко живёт человек, вот я на самом конце деревни, мне Валя часто: "Ну, ты как Саня пеномская! Живешь гдето на хуторе"» (с. Тихон, Тихоновская с/адм).

\section{$\Delta$ Пе́нома, д.}

КАК САНЯ ТАГА́НСКАЯ СИДЕТЬ. Не сидеть на месте, ёрзать (Окт.). «Ты что как Саня таганская выгибаешься» (д. Лямино, Власовская с/адм). А Тага́нка, пос.

РАЗБЛАЖИТЬСЯ КАК СИДОРКА ТЯ́ПНИНСКИЙ. О вспыльчивом человеке (Парф.). «Говорят: "Разблажился как Сидорка тяпнинский”. Он жил в этом Тяпневе, очень по характеру был горячий, а фамилия была Сидоров. Так говорят, когда горячий, когда вспыльчивый, из рамок человек» (с. Никулино, Ширская с/адм).

\section{А Тйпнево, д.}

КАК СТЁПКА МА́СЛОВСКИЙ. О ГЛУПОМ человеке (Буйск.). «Ты дурачок, как Стёпка масловский. Был Степка дурачок в Маслове. Парень или мужчина дурачок, говорили: “Ну, ты как Стёпка масловский. Стёпка возил молоко в Маслове"» (с. Шушкодом, Шушкодомская с/адм).

\section{А Масло́во, д.}

КАК ФЕДЯ ПАРЮГСКО́Й. О сумасшедшем человеке (Вохом.). «У нас Федя был такой, немножко вот такой парень. У нас был такой дурачок, и из-за этого все говорят: “Ну, как Федя". „Ой, - говорят, - как Федя парюгской”. На Парюге он был-то» (с. Тихон, Тихоновская с/адм).

\ Малый Па́рюг, д.

ЯКИМ СА́ЛОВСКИЙ. Простак, простофиля (Макар.). «Простой-общой, кто всё отдаст, доброй-от какой, что как Яким саловской всё отдал, нынче нет таких людей, мало простофиль» (д. Фролово, Нежитинская с/адм). $\boldsymbol{\Delta}$ Са́лово, д.

\section{Список источников}

Воронщова Ю. Б. Словарь коллективных прозвищ. М.: АСТ-ПРЕСС КНИГА, 2011. 448 с.

Даль В. И. Толковый словарь живого великорусского языка: в 4 т. [Репр. изд.] СПб.: Диамант, 1996.

Даль ПРН ${ }_{2}-$ Пословищы русского народа: в 3 т. / сб. В. Даля. М.: Русская книга, 1993.

КСГРС - картотека «Словаря говоров Русского Севера» (хранится на кафедре русского языка, общего языкознания и речевой коммуникации Уральского федерального университета, Екатеринбург).

ЛК ТЭ - лексическая картотека Топонимической экспедиции Уральского университета (хранится на кафедре русского языка, общего языкознания и речевой коммуникации Уральского федерального университета, Екатеринбург).

СППП - Словарь псковских пословиц и поговорок / сост. В. М. Мокиенко, Т. Г. Никитина. СПб.: НОРИНТ, 2001. 173 с.

СРГК - Словарь русских говоров Карелии и сопредельных областей: в 6 вып. / гл. ред. А. С. Герд. СПб.: Изд-во С.-Петерб. ун-та, 19942005.

СРНГ - Словарь русских народных говоров / гл. ред. Ф. П. Филин (вып. 1-22); Ф. П. Сороколетов (вып. 23-42); С. А. Мызников (вып. 43-). М.; Л.; СПб.: Наука, 1965-. Вып. 1-.

Фасмер М. Этимологический словарь русского языка: в 4 т. / пер. с нем. и доп. О. Н. Трубачева. М.: Прогресс, 1964-1973.

ФСПГ - Прокошева К. Н. Фразеологический словарь пермских говоров. Пермь: Изд-во Перм. гос. пед. ун-та, 2002. 431 с.

ЯОС - Ярославский областной словарь / отв. ред. Г. Г. Мельниченко: в 10 вып. Ярославль: Ярослав. гос. пед. ин-т им. К. Д. Ушинского, 1981-1991.

\section{Список литературы}

Березович Е. Л. Местные топонимы в свете деривационной и фразеологической семантики // Язык и прошлое народа: сб. науч. ст. памяти проф. А. К. Матвеева. Екатеринбург: Изд-во Урал. гос. ун-та, 2012. С. 25-52. 
Березович Е. Л. Славянские оттопонимические названия жителей как источник семантической деривации // XVI Международный съезд славистов. Белград, 20-27 августа 2018 г. Доклады российской делегации. М.: Ин-т славяноведения РАН, 2018. С. 7-34.

Варбот Ж. Ж. Исследования по русской и славянской этимологии. М.; СПб.: Нестор-История, 2012. $648 \mathrm{c}$.

Виноградов В.В. История слов: около 1500 слов и выражений и более 5000 слов, с ними связанных / отв. ред. Н. Ю. Шведова. М.: Толк, 1994. $1138 \mathrm{c}$.

Генералова E. В. О развитии значений оттопонимических прилагательных в русском языке (на примере истории лексемы московский) // Сибирский филологический журнал. 2016. № 3. С. $157-171$.

Казакова Е. В. Вятка и вятчане в русской языковой традиции // Вопросы ономастики. 2011. № 2(11). С. 19-50.

Коган E. С. Имя собственное в диалектном фразеологизме: этапы идиоматизации // Вопросы ономастики. 2014. № 1(16). С. 122-127.

Левашов Е. А. Словарь прилагательных от географических названий. М.: Рус. яз., 1986. 550 с.

Правила русской орфографии и пунктуации: полный академический справочник / под ред. В. В. Лопатина. М., 2011. С. 150-154.

Озтюрк Л. И. Региональный аспект в исследованиях адъектонимии современного русского языка // Вестник Чувашского университета. Гуманитарные науки. 2008. № 4. С. 229-236.

Родионова И. В. Характерологические номинации антропонимического происхождения в русских народных говорах // Русский язык в научном освещении. 2005. № 2(10). С. 159-189.

Смольников С. Н. Актуальная и потенциальная русская антропонимия // Вопросы ономастики. 2005. № 2. С. 23-35.

Феоктистова Л. А. Лексика и фразеология с антропонимическим компонентом в говорах Поветлужья // Национально-культурный и когнитивный аспекты изучения единиц языковой номинации: материалы междунар. науч.-практ. конф. 2224 марта 2012 г. / под науч. ред. А. М. Мелерович. Кострома: КГУ им. Н. А. Некрасова, 2012. C. 259-261.

\section{References}

Berezovich E. L. Mestnye toponimy $\mathrm{v}$ svete derivatsionnoy i frazeologicheskoy semantiki [Local toponyms in the light of derivational and phraseological semantics]. Yazyk i proshloe naroda: sbornik nauchnykh statey pamyati prof. $A$. K. Matveeva [The people's language and past: collection of scientific articles in memory of Prof. Alexander K. Matveev].
Ekaterinburg, Ural Federal University Press, 2012, pp. 25-52. (In Russ.)

Berezovich E. L. Slavyanskie ottoponimicheskie nazvaniya zhiteley kak istochnik semanticheskoy derivatsii [The Slavic names of inhabitants derived from toponyms as a source of semantic derivation]. XVI Mezhdunarodnyy s'ezd slavistov. Belgrad, 2027 avgusta $2018 \mathrm{~g}$. Doklady rossiyskoy delegatsii [XVI International Congress of Slavists. Belgrade, 20-27 August 2018. Papers of the Russian delegation]. Moscow, Institute of Slavic Studies of the RAS Publ., 2018, pp. 7-34. (In Russ.)

Varbot Zh. Zh. Issledovaniya po russkoy $i$ slavyanskoy etimologii [Research on Russian and Slavic Etymology]. Moscow, St. Petersburg, NestorIstoriya Publ., 2012. 648 p. (In Russ.)

Vinogradov V. V. Istoriya slov: okolo 1500 slov $i$ vyrazheniy $i$ bolee 5000 slov, s nimi svyazannykh [The History of words: about 1,500 words and expressions and more than 5,000 words related to them]. Ed. by N. Yu. Shvedova. Moscow, Tolk Publ., 1994. 1138 p. (In Russ.)

Generalova E. V. O razvitii znacheniy ottoponimicheskikh prilagatel'nykh $\mathrm{v}$ russkom yazyke (na primere istorii leksemy moskovskiy) [About semantic development of the adjectives formed from place names in the Russian language (at the example of the history of the word «Moscow» («Muscovite»)]. Sibirskiy filologicheskiy zhurnal [Siberian Journal of Philology], 2016, issue 3, pp. 157-171. (In Russ.)

Kazakova E. V. Vyatka i vyatchane v russkoy yazykovoy traditsii [Vyatka and Vyatkans in the Russian linguistic tradition]. Voprosy onomastiki [Problems of Onomastics], 2011, issue 2(11), pp. 19-50. (In Russ.)

Kogan E. S. Imya sobstvennoe v dialektnom frazeologizme: etapy idiomatizatsii [Proper names in dialectal idioms: stages of idiomatization]. Voprosy onomastiki [Problems of Onomastics], 2014, issue 1(16), pp. 122-127. (In Russ.)

Levashov E. A. Slovar' prilagatel'nykh ot geograficheskikh nazvaniy [The Dictionary of adjectives derived from geographical names]. Moscow, Russkiy Yazyk Publ., 1986. 550 p. (In Russ.)

Pravila russkoy orfografii $i$ punktuatsii: polnyy akademicheskiy spravochnik (razdel «Geograficheskie $i$ administrativno-territorial 'nye nazvaniya i proizvodnye ot nikh slova», $\$ 177$ ) [The rules of Russian orthography and punctuation: complete academic reference book (section "Geographical and administrative-territorial names and words derived from them", $\S 177)$. Ed. by V. V. Lopatin. Moscow, 2011, pp. 150-154. (In Russ.)

Oztyurk L. I. Regional'nyy aspekt v issledovaniyakh ad'ektonimii sovremennogo russkogo yazyka [The regional dimension in the study of toponymic adjectives of the modern Russian language]. Vestnik 
Chuvashskogo universiteta. Gumanitarnye nauki [Bulletin of the Chuvash University. Series of Humanities], 2008, issue 4 (16), pp. 229-236. (In Russ.)

Rodionova I. V. Kharakterologicheskie nominatsii antroponimicheskogo proiskhozhdeniya $\mathrm{V}$ russkikh narodnykh govorakh [Characterological nouns formed from anthroponyms In Russian dialects]. Russkiy yazyk v nauchnom osveshchenii [Russian Language and Linguistic Theory], 2005, issue 2 (10), pp. 159-189. (In Russ.)

Smolnikov S. N. Aktual'naya i potentsial'naya russkaya antroponimiya [Actual and Potential Russian Anthroponymy]. Voprosy onomastiki [Problems of Onomastics], 2005, issue 2(10), pp. 23-35. (In Russ.)
Feoktistova L. A. Leksika i frazeologiya s antroponimicheskim komponentom $\mathrm{v}$ govorakh Povetluzh'ya [Vocabulary and phraseology with anthroponymic components in the dialects of the region of Vetluga]. Natsional'no-kul'turnyy $i$ kognitivnyy aspekty izucheniya edinits yazykovoy nominatsii: materialy mezhdunar. nauch.-prakt. konf. 22-24 marta $2012 \mathrm{~g}$. [National-cultural and cognitive aspects of studying units of language nomination: proceedings of international scientificpractical conference, 22-24 March 2012]. Ed. by A. M. Melerovich. Kostroma, Kostroma State University named after N. A. Nekrasov Press, 2012, pp. 259-261. (In Russ.)

\title{
COMPARATIVE STRUCTURES WITH A PERSONAL NAME AND AN ADJECTIVE DERIVED FROM A TOPONYM IN THE DIALECTS OF THE KOSTROMA REGION
}

\author{
Julia A. Krivoshchapova \\ Associate Professor in the Department of Philology of the Specialized Education and Research Center \\ Ural Federal University named after the first President of Russia B. N. Yeltsin \\ 30, Danily Zvereva st., Ekaterinburg, 620137, Russian Federation. insekt@yandex.ru \\ SPIN-code: $2680-6403$ \\ ORCID: https://orcid.org/0000-0003-3096-708X \\ ResearcherID: Q-3496-2018
}

\section{Lyubov A. Feoktistova}

Associate Professor in the Department of Russian Language, General Linguistics and Verbal Communication Ural Federal University named after the first President of Russia B. N. Yeltsin

51, Lenina prospekt, Ekaterinburg, 620000, Russian Federation.1.a.feoktistova@urfu.ru

SPIN-code: $2851-9740$

ORCID: https://orcid.org/0000-0001-6640-4815

ResearcherID: T-7885-2017

\section{Submitted 08.09.2018}

The article deals with comparative structures found in the dialects of the Kostroma region which include a personal name and an adjective derived from an oikonym: kak Dunya kasimovskaya $<$ like Dunya kasimovskaya> (< village Kasimovo) 'about an awkwardly dressed woman', kak Fedya páryugskiy <like Fedya paryugskiy> (< village Malyi Paryug) 'about a mad person', and so on. These idioms characterize a person whose behavior does not conform to the norms of the village (and not only) community (cf. kak Sanya pénomskaya $<$ like Sanya pénomskaya $>$ 'about a woman living away from other people'). These idioms are discussed in terms of their structure and semantics, as well as the functions and onomastic status of their constituents. The authors note that the comparison is not always explicitly expressed and can include different predicates (Chto naryadilsya, kak Anis'ya klimovskaya?! <Why are you dressed up like Anisya klimovskaya?>; Anis'ya klimovskaya idet <Anisya klimovskaya is walking along >). The personal name is often presented by a diminutive, the adjective is usually in the postposition. Particular attention is paid to the analysis of the semantic "behavior" of the personal name and the adjective. According to the authors, in comparative structures personal names in combination with adjectives derived from toponyms have the same semantic peculiarities as common derivatives of single personal names: dominance of the negative, diffusivity of meaning and/or polysemy, expressiveness. It is argued that such anthroponyms function as nominationcharacteristics and are at the first level of semantic derivation and appellativization. However, the adjective is little exposed to semantic transformations within idioms. Its basic function of geo-referencing the object remains unchanged, which, to a certain extent, restrains appellativization of the anthroponym, thus reminding that the nomination is based on the comparison with a real person.

Key words: appellativization of proper names; proper name; personal name; adjective derived from a toponym; comparative structure; phraseological unit; semantic derivation; Kostroma dialects. 